\title{
MELAWAN DOMINASI PENGUASA: WACANA DEMOKRASI DELIBERATIF UNTUK INDONESIA
}

\author{
Asmaul Husna \\ Universitas Teuku Umar \\ Email: asmaulhusna@utu.ac.id
}

\begin{abstract}
Almost twenty one years Indonesia escape from the clutches from the regime of Orde Baru, in fact this nation does not necessarily become a democratic nation. The concept of citizenship embodied in the fourth principle of Pancasila which should interpreted as a citizen of the owner of supreme sovereignty in a country, it misinterpreted into objects which is influenced by the wisdom of the authorities, and the implementation of democracy is run solely limited to compliance with the rules and not within the framework to empower citizens. In the middle uncertainty of finding the ideal form of democracy, appear discourse on deliberative democracy which emphasizes the active participation of citizens through the media and the vocal organizations to play a very significant influence in the process of establishing the legal and political policies. If we explored it more deeply, this idea looks similar to the idea of Democracy of Pancasila which was popularized by the founding fathers of Indonesia. Offering a more humanistic approach, egalitarian, and accommodating this idea seems quite interesting if it actually implemented in Indonesia.
\end{abstract}

Keyword: Citizens, Deliberative, Democracy, Participation.

\section{PENDAHULUAN}

Demokrasi adalah sebuah konsep yang diperkenalkan oleh Aristoteles dan berasal dari bahasa yunani yaitu demos dan kratos. Demos yang berarti rakyat dan kratos yang artinya kekuasaan, namun rakyat dalam hal ini bukanlah rakyat secara keseluruhan, melainkan mereka yang berdasarkan kesepakatan formal mengontrol sumber kekuasaan dan bisa mengklaim kepemilikan ats hak-hak individu dalam proses pengambilan keputusan yang menyangkut dengan urusan publik atau pemerintahan (Soemarsono, 2009). Maka dengan kata lain demokrasi dapat diartikan sebagai sebuah bentuk pemerintahan yang kekuasaan pemerintahannya itu berasal dari rakyat, untuk rakyat, dan oleh rakyat atau yang berarti juga tiap warga negara berfungsi sebagai subjek sekaligus objek dari sebuah sistem itu 
sendiri. Demokrasi Indonesia dapat dipahami sebegai suatu mekanisme dan citacita hidup berkelompok dalam organisasi negara yang menurut Undang-Undang dasar 1945 disebut sebagai kerakyatan.

Harus diakui dalam membangun sebuah negara yang demokratis tidaklah semudah membalikkan telapak tangan, pasang surut tentu saja dialami dalam perjalannya. Hal ini terbukti, setelah hampir dua puluh satu tahun Indonesia lepas dari cengkraman Orde Baru nyatanya bangsa ini tidak serta merta menjadi bangsa demokrasi. Demokrasi yang terjadi saat ini masih sebatas pemaknaan simbol ketimbang makna subtantifnya. Maka wajar jika kemudian muncul istilah demokrasi prosedural, dimana konsep demokrasi banyak disalah gunakan dan hanya dijalankan sebatas pemenuhan aturan main semata dan bukan dalam kerangka memberdayakan warga negara (Fatkhurohman, 2010).

Sebagai contoh tuntutan keterlibatan warga negara dalam ajang rutin lima tahunan untuk memilih wakil rakyat yang nyata-nyata tidak lagi responsif terhadap aspirasi mereka justru mengakibatkan warga negara menjadi semakin apatis dan cenderung skeptis terhadap kehidupan politik yang mewujud dalam bentuk Golput serta dan bentuk-bentuk keputus asaan lain. Padahal yang diharapkan warga negara sesungguhnya ialah praktik demokrasi yang merasuk hingga ranah substansial, layaknya aspek-aspek sosial, ekonomi, budaya dan bukan hanya pada ranah politik saja (Priyono, 2014). Indonesia sebagai negara yang bersistem pemerintahan demokrasi dan berazaskan pancasila, maka sudah sepantasnyalah pemerintah berkewajiban memfokuskan perhatiannya kepada kepentingan warga negaranya dalam rangka mewujudkan kesejahteraan ekonomi yang merata dan adil, mengingat merekalah pemilik kekuasaan tertinggi sesungguhnya.

Di tengah kegamangan pencarian bentuk demokrasi ideal bagi Indonesia dan minimnya ruang publik yang mampu menampung aspirasi warga negara, muncul gagasan menarik mengenai demokrasi deliberatif. Dimana pada konsep demokrasi deliberatif menekankan peran serta warga negara melalui media dan organisasi yang vokal untuk memainkan pengaruh yang sangat signifikan dalam proses pembentukan hukum dan kebijakan politik yang ada. Secara tidak langsung 
gagasan ini tampak serupa dengan gagasan demokrasi pancasila yang sempat dipopulerkan oleh para founding fathers Indonesia di masa lampau. Hal inilah yang kemudian menjadikan gagasan demokrasi deliberatif ini menarik untuk dieksplorasi lebih dalam yang kemudian akan dibandingkan dengan gagasan demokrasi pancasila yang sejatinya telah dimiliki oleh Indonesia. Selanjutnya juga akan dibahas mengenai pemafaatan media dalam menunjang partisipasi politik aktif di Indonesia saat ini.

\section{DEMOKRASI DELIBERATIF MILIK HABERMAS}

Demokrasi deliberatif pertama kali diperkenalkan oleh J.M Bassette yang kemudian dipopulerkan dan dikembangkan oleh Jurgen Habermas dalam rangka merevitalisasikan kembali pemikiran ataupun esensi mengenai konsep hukum, negara dan demokrasi yang mana pada masa itu sangat didominasi oleh paham radikal milik John Locke dan Rousseau. Dimana John Locke dengan paham liberal memandang hukum dan negara secara utilitaristik sebagai lembaga yang wajib menjamin kebebasan dan kebutuhan warga negaranya. Sedangkan Rousseau memandang hukum sebagai ekspresi kehendak umum, kehendak suci rakyat. Republikanisme menegaskan bahwa negara tidak dapat berdiri jika hanya dianggap sebagai sarana pelayanan kebebasan individual, melainkan negara juga berhak menuntut komitmen dan pengorbanan dari warga negara. Sehingga mengabdikan diri pada negara diibaratkan sebagai sebuah tugas suci (Habermas, 1998).

Kata deliberatif sendiri berasal dari kata dalam bahasa Latin deliberatio yang memiliki arti konsultasi, menimbang-nimbang, atau proses musyawarah (Hardiman, 2009). Gagasan deliberatif ini sebenarnya merupakan sebuah jalan guna merealisasikan demokrasi yang sesungguhnya. Menurut pandangan Habermas sebuah negara hukum tidak dapat diperoleh maupun dipertahankan tanpa adanya proses demokrasi yang radikal, karena dalam demokrasi deliberatif sendiri terdapat tiga prinsip utama yaitu deliberasi, reasonableness, dan kesetaraan kedudukan. 
Proses demokrasi baru bisa dikatakan deliberatif apabila pembentukan kebijakankebijakan publik diuji dan diperdebatkan terlebih dahulu melalui diskursus atau konsultasi di ruang publik, sehingga semua pihak yang terkait memiliki peluang dan kebebasan yang sama dalam menyampaikan argumentasi, pertimbangan, dan gagasannya secara terbuka (Habermas, 1989). Dengan demikian upaya ini diharapkan dapat meminimaisir munculnya kepentingan mayoritas yang mendominasi seluruh kebijakan yang cenderung menguntungkannya. Atau dengan kata lain demokrasi deliberatif adalah menekankan legitimasi dari proses politik pada kegiatan dialog dan partisipasi politik warga negara dalam upaya pengambilan keputusan publik dan bukan pada hasil yang dicapai.

Dalam gagasan demokrasi deliberatif, negara tidak lagi perlu menentukan kebijakan publik dan politik lainnya, tetapi warga negaralah yang memainkan pegaruhnya melalui media dan organisasi yang vokal secara signifikan agar kebijakan dipersiapkan dan diarahkan secara diskursif (Suhelmi, 2001). Namun bukan berarti warga negara dapat megintervensi langsung ruang publik ke dalam sistem politik yang ada, melainkan peran politik yang aktif dari warga negara guna membangun opini mereka sendiri secara publik dalam mengontrol dan mengendalikan arah pemerintahan secara tidak langsung melalui diskursusdiskursus.

Dalam demokrasi liberatif kekuasaan komunikatiflah yang memegang peranan penting. Dimana kekuasaan ini terbentuk melalui forum diskusi publik dan diakui secara faktual atas klaim-klaim keseluruhan yang terbuka terhadap kritik dan dicapai secara diskursif (Hardiman, 2009). Dengan begitu demokrasi deliberatif akan menghasilkan komunikasi dua arah antara penguasa dengan warga negara yang kemudian akan melunturkan dominasi di dalamnya. Pada tahap ini konsep demokrasi dan kedaulatan rakyat akan menjadi jauh lebih bermakna, di mana rakyat mempunyai hak untuk selalu mengintervensi negara dalam proses pembuatan kebijakan publik.

Berdemokrasipun bukan lagi sekedar proses pengabilan keputusan di parlemen, melainkan juga dalam proses penyusunan anggaran, kritik terhadap pemerintah, 
dan menyalurkan aspirasi. Oleh karena itulah warga negara dituntut aktif dalam menyelesaikan persoalan pembangunan secara aktif. Karena itulah logika pengambilan kebijakan publikpun juga harus mulai bergeser menjadi logika partisipatoris.

\section{INDONESIA DAN DEMOKRASI}

Jauh sebelum era reformasi di mulai, Indonesia sesungguhnya telah menganut sistem demokrasi pancasila sebagai betuk pemerintahannya, meskipun dalam perjalanannya cenderung tampak layaknya pemerintahan otoriter. Demokrasi pancasila sendiri ialah demokrasi yang berdasarkan pada kedaulatan rakyat yang dijiwai serta dintegrasikan dengan sila-sila yang telah dituangkan para founding fathers dalam pancasila seperti yang termaktumkan dalam pembukaan Undang Undang Dasar 1945. Hal ini memiliki arti bahwa dalam menggunakan hak-hak demokrasi para warga negara haruslah selalu disertai dengan rasa tanggung jawab kepada Tuhan Yang Maha Esa, menjunjung tinggi nilai-nilai kemanusiaan sesuai dengan martabat dan harkat kemanusiaan, selain itu juga haruslah menjamin dan memperkokoh persatuan bangsa dan harus dimanfaatkan untuk mewujudkan keadilan sosial (Madjid, 2003).

Asas-asas dari demokrasi pancasila sendiri terbagi menjadi tiga bagian. Pertama, asas kerakyatan yang memiliki makna bahwa rakyat adalah pemangku dan penegak kedaulatan (kekuasaan) tertinggi di dalam negara, sehingga aspirasi rakyat hendaknya menjadi pusat pertimbangan dalam menetapkan kebijakan negara. Kedua, asas hikmat kebijaksanaan yang memiliki makna bahwa seorang pemimpin hendaknya bersikap dan bertindak bijaksana, adil, dan mengayomi. Ketiga, asas permusyawaratan yang memiliki makna bahwa wakil rakyat yang dipilih dari dan oleh rakyat melalui Pemilihan Umum wajib melaksanakan musyawarah untuk menetapkan sebuah kebijaksanaan (Syam, 2003).

Dengan demikian secara tidak langsung sistem demokrasi pancasila yang dianut Indonesia sejak era orde baru sejatinya selaras dengan gagasan demokrasi liberatif 
milik Habermas. Dimana kedua gagasan ini percaya bahwa demokrasi harus benarbenar mengutamakan musyawarah dan keberadaan warga negara dalam proses pembentukan kebijakan politis yang berkenan dengan kepentingan publik secara diskursif-argumentatif guna mencapai kata mufakat.

Namun, tentu saja kenyataan yang terjadi di lapangan tidaklah seindah dalam teoriteori yang dituiskan oleh filusuf dalam buku-bukunya. Demokrasi di Indonesia masih terbatas pada persoalan pemilihan umum, partai politik, parlemen, dan halhal yang seputaran itu saja tanpa pernah menyentuh diskursus mengenai demokrasi di ruang informal. Praktis kebijakan yang dihasilkan oleh aktor-aktor legislatif dan eksekutif yang berorintasi pad state-centrist (Priyono, 2014).

Bahkan konsep kerakyatan yang dituliskan dalam sila keempat pancasila yang seharusnya diartikan sebagai warga negara pemilik kedaulatan tertinggi dalam sebuah negara, justru disalah artikan menjadi objek yang dipengaruhi oleh kebijaksanaan penguasa, sedangkan demokrasi dijalankan dalam bentuk permusyawaratan yang diwakili oleh segelintir individu dan seringkali tanpa mendengarkan aspirasi rakyat.

Warga negara tidak benar-benar paham mengenai hak dan kewajiban mereka dalam konsep demokrasi. Padahal posisi mereka sungguh krusial sebagai bagian dalam negara berdemokrasi yang memiliki cita-cita mensejahterakan warganya. Sistem pemerintahan dan kebijakan publik seharusnya tidak melulu diatur oleh mereka yang duduk di kursi parlemen dengan mengatas namakan diri sebagai wakil rakyat, akan tetapi seharusnya juga melibatkan peran warga negara di dalam perumusannya. Namun kenyataannya peran itu hanya sampai pada partisipasi perayaan lima tahunan semata.

Dengan kegagalan yang dihadapi, bukan berarti negara harus dibubarkan begitu saja melainkan negara hukum dan konstitusi harus tetap ada sebagaimana adanya. Akan tetapi kanal-kanal komunikasi dalam negara hukum harus dibuka, sumbatansumbatan dihilangkan, parlemen diharapkan semakin mendengar, media berbicara semakin lantang dalam mengontrol penyimpangan hingga menghasilkan wacana 
yang fair (Hardiman, 2009). Dengan demikian, prinsip-prinsip negara hukum harus tetap ada sehingga state dan society memiliki perbedaan yang nyata siapa yang dipimpin dan siapa yang memimpin. Karena sesungguhnya demokrasi yang diperankan bukan demokrasi langsung, melainkan hanya kontrol diskursif atas kinerja aktor legislatif dan eksekutif dari sebuah negara.

Negara harus benar-benar bisa menjamin serta mengakomodasikan aktifitas demokrasi yang sehat bagi warga negaranya. Adanya partisipasi akan mentransformasikan posisi individu menjadi warga negara yang demokratis, dimana mereka dapat mengklarifikasikan dan memperjelas kebutuhan dan kepentingannya secara lebih terbuka serta meningkatkan kesadaran dan ketrampilan politik mereka (Habermas, 1989). Selain itu partisipasi juga akan mendorong warga negara untuk lebih percaya terhadap state serta menumbuhkan rasa tanggung jawab untuk turut serta mewujudkan kemajuan bersama. Karena sejatinya partisipasi tidak cukup hanya dilakukan segelintir orang yang duduk dalam lembaga perwakilan karena institusi dan orang-orang yang duduk dalam lembaga perwakilan seringkali mengggunakan politik atas nama kepentingan rakyat untuk memperjuangkan kepentingan pribadi atau kelompok mereka sendiri.

Harus disadari benar bahwa perwakilan saat ini tidak lagi bisa diharapkan guna menampung usulan minoritas maupun mengesahkan pengakuan terhadap pluralitas, melainkan harus bertransformasi menjadi media publik dalam upaya penegasan partisipasi dalam perusyawaratan yang kemudian memberikan state wewenang sebagai penyangga legalitas. Karena sejatinya permusyawaratan merupakan afirmasi penegasan otoritas individu untuk berbagi pemaknaan dengan memanfaatkan kolektivitas sebagai ruang yang dinamis yang kiraya dapat menghilangkan gap dan melunturkan dominasi yang ada sebelumnya. Atau dengan kata lain sudah saatnya Indonesia mulai melakukan refleksi dan desain ulang atas pemaknaan konsep permusyawaratan. 
Di tengah kegamagan warga negara mencari ruang publik yang benar-benar mampu menghasilkan wacana yang fair dalam negara demokrasi, kemajuan teknologi dan informasi komunikasi seolah membuka harapan baru mengenai hal tersebut. Internet dengan daya jangkau dan kecepatan yang dimilikinya telah menjelma sebagai sumber utama informasi bagi kebanyakan orang di berbagai belahan dunia. Internet menciptakan terbentuknya masyarakat yang melek akan informasi, sebuah well-informed citizenry (Lee, 2011). Dimana dalam hal ini internet juga telah bereran dalam mendidik warga negara tentang apa itu demokrasi dan membantu mereka tetap up to date dengan apa yang terjadi dalam pemerintahan.

Tidak hanya itu, internet juga menawarkan perubahan corak komunikasi politik dan menguatkan akses partisipasi politik warga negara yang lebih luas dan lebih aktif seperti memungkinkan terjadinya debat-debat publik, mengkritisi dan menganalisis berbagai keputusan publik, serta perubahan paradigma pemikiran warga negara dalam upaya mengatasi polemik publik secara efisien, efektif dan harmonis. Dengan kata lain, internet berperan vital dalam mempercepat perwujudan demokrasi yang sesungguhnya. Penyebaran informasi gratis melalui internet telah mendorong kebebasan berpendapat, berekspresi, berserikat, peningkatan pengetahuan serta keterlibatan warga negara dalam ranah politik serta terbangunnya peradaban baru umat manusia. Internet adalah perpanjangan tangan demokrasi yang nenawarkan konsep ruang publik gaya baru yang lebih luas dan mudah diakses masyarakat dengan media baru sebagai variabel penting di dalamnya (Jafarkarimi, 2014).

Media sosial dengan berbasis internet memiliki perbedaan yang cukup signifikan dari segi karakteristik dengan media konvensional, baik dalam hal isi, fungsi, institusi, maupun aksesbilitasnya. Dalam konteks isi, media baru diketahui memiliki karakteristik cepat, informatif, tidak terbatas, transparan, konvergen, dan global. Dalam konteks fungsi, media baru lebih dapat menembus semua kalangan dengan akses yang lebih universal. Dalam konteks institusi, media baru cenderung terdesentralisasi, virtual, dan fleksibel. Dan dalam konteks aksesibilitasnya, media 
baru cenderung lebih interaktif, bebas, dan setara (Nurudin, 2012). Ketika konsep mengenai demokrasi digambarkan dengan nilai-nilai kesetaraan, toleransi atas perbedaan, kebebasan, partisipasi, serta perlindungan atas hak asasi, maka hal itu semua dapat terakomodir dengan sempurna dalam media baru.

Media baru juga disebut-sebut memiliki watak partisipatoris karena dirancang untuk memungkinkan setiap individu menjadi memiliki peluang keterlibatan yang sama sebagai pencipta sekaligus penikmat yang lebih independen dengan memberikan ruang bebas yang ditopang prinsip kesetaraan. Dimana media sosial mengembangkan tiga jenis partisipasi. Pertama, partisipasi kebijakan untuk mendukung atau menentang kebijakan seperti konsultasi online, survei dan polling online, voting elektronik, hingga referenda. Kedua, partisipasi politik, yaitu guna mempengaruhi proses pembuatan kebijakan dan keputusan politik. Terakhir, partisipasi sosial yaitu peningkatan modal sosial seperti solidaritas atau petisi publik, misalnya melalui apa yang disebut Web 2.0. Dengan kemampuan tersebut maka tidak salah jika kemudian muncul istilah bahwa media baru diibaratkan layaknya jantung dari sistem demokrasi (Towner, 2013). Dengan demikian media baru juga telah bertransformasi menjadi fasilitator guna terjalinnya hubungan komunikatif yang lebih dekat antara warga negara dengan state.

Partisipasi politik online di Indonesia dalam beberapa tahun belakangan memang meningkat pesat, bahkan jika ditelisik lebih dalam tepatnya dua puluh satu tahun silam nyatanya media baru bahkan memiliki peran yang cukup penting dalam upaya penggulingan Rezim Orde Baru. Dima setidaknya dua tahu terakhir masa pemeritahan Presiden Soeharto, internet digunakan secara luas oleh kelompok oposisi dari golongan kelas menengah dan golongan pro-demokrasi untuk menyiasati sensor media oleh tirani (Sen, 2000). Para aktivis pro-demokrasi menggunakan internet guna merencanakan pergerakan yang berujung pada takluknya rezim otoriter masa itu.

Namun tampaknya pergerakan kolektif dan partisipatif warga negara sebesar itu mandeg di tahun 1998. Di masa era ini, meskipun Indonesia menduduki peringkat cukup tinggi dalam hal akses media sosial, nyatanya hal ini tidak dibarengi dengan 
peningkatan kualitas demokrasi, baik dari segi jenis informasi maupun dampak serta pengaruh politik yang muncul. Tampaknya bangsa Indonesia terlalu terbuai dengan kemudahan yang ditawarkan oleh media baru. Kemudahan untuk sekadar memposting informasi ataupun membagikan pesan-pesan politik melalui media baru, membuat orang-orang lebih peduli dengan realitas layar dari pada fisik (Supelli, 2010). Setiap orang degan mudah melempar argumen dan berkomentar mengenai bermacam-macam persoalan, tetapi tidak ada seorangpun yang bersedia terlibat langsung dalam gerakan politik yang nyata atau bahkan sedikit saja merasa memiliki tanggung jawab di dalamnya.

Fenomena ini disebut dengan political passivity, yaitu ketika warga negara memiliki harapan-harapan yang tinggi terhadap pemerintah namun enggan terlibat dalam aksi politik, sebagian warga negara bahkan mengambil bagian dalam politik seperti yang dilakukan dalam olahraga atau musik, yaitu dengan menjadi fans ketimbang peserta (May, 2008). Publik terjebak kedalam pemberdayaan semu, dimana setiap orang mengira opini yang ia lontarkan dan sebar seluaskan memiliki dampak bagi kebaikan bersama, padahal hal itu hanya mengambang di sudut maya. Mereka merasa sudah sangat produktif dengan apa yang mereka lakukan, padahal yang dikerjakan hanya mengumpulkan informasi, mengomentarinya dan meneruskannya ke orang-orang lain. Alih alih ingin menghancurkan dominasi mereka justru tengah melakukan percakapan semu tanpa dialog, ataupun adu argumentasi yang menggunakan rasio yang pada gagasan demokrasi sangat ditekankan. Maka jika demikian fungsi media baru yang diharapkan semula sebagai konstelasi ruang publik komunikatif masih jauh dari panggang daripada api.

\section{PENUTUP}

Serangan media baru di Indonesia nampakya tidak dibarengi dengan kesadaran warga negara untuk mengaktualisasikan diri mereka melalui partisipasi politik yang lebih konkrit. Warga negara masih berkutat dalam hal mengekspresikan opini 
tanpa mau mengambil bagian di dalamnya karena merasa minim pengalaman dan pemahaman megenai politik. Padahal sejatinya warga negara harus sadar dengan benar bahwa sejatinya negara demokrasi tidak akan berdiri dengan kokoh bila tanpa keterlibatan warga negara di dalamnya. Tidak ada yang remeh temeh dalam forum-forum berbasis agumentasi deliberatif.

Muncul dengan gagasan demokrasi deliberatif, Jurgen Habermas mengingatkan kembali bangsa Indonesia mengenai demokrasi pancasila dimana keduanya samasama memandang bahwa partisipasi dan musyawarah adalah prinsip utamanya. Negara harus benar-benar hadir dan bisa menjamin serta mengakomodasikan aktifitas demokrasi partisipatif yang sehat bagi warga negaranya, pengambilan kebijakan publikpun juga harus mulai bergeser menjadi logika partisipatoris. Namun tentu saja bukan berarti warga negara mendapatkan legalitas dalam melakukan intervensi pada sistem pemerintahan secara bebas tak terkendali, melainkan hanya kontrol diskursif atas kinerja aktor legislatif dan eksekutif dari sebuah negara. Menawarkan pendekatan yang lebih humanistik, egaliter, dan akomodatif tampaknya gagasan ini cukup menarik jika kemudian benar-benar diterapkan di Indonesia. Semoga bangsa ini masih mau dan mampu berbenah.

\section{REFERENSI}

Buku

Hardiman, B.F. (2009). Demokrasi Deliberatif: Menimbang Negara Hukum dan Ruang Publik Dalam Teori Diskursus Jurgen Hubermas. Yogyakarta: Kanisius

Habermas, J. (1998). The Inclusion of Other: Studies in Politic Theory. Cambridge: MIT Press

Habermas, J. (1989). Between Facts and Norms: Contribution to a Discourse Theory of Law and Democracy. Cambridge: MIT Press 
Madjid, N. (2003). Indonesia Kita. Jakarta: Paramadina

May, T. (2008). The Political Thought of Jacques Rancière: Creating Equality. Edinburgh University Press.

Nurudin. (2012). Media Sosial Baru Dan Munculnya Revolusi Baru Proses Komunikasi. Buku Litera: Yogyakarta

Priyono, A.E., \& Usman H. (2014). Merancang Arah Baru Demokrasi: Indonesia Pasca-Reformasi. Jakarta: Kepustakaan Populer Gramedia

Sen, K. \& David H. (2007). Media, Culture and Politics ind Indonesia. Jakarta: Equinox Publishing Indonesia

Soemarsono, H. (2009). Paradoks Demokrasi: Politik, Polemik dan Problematik: Demokratisasi dan Relokasi Kekuatan di Indonesia. Jakarta: Indhill Co

Suhelmi, A. (2001). Pemikiran Politik Barat: Kajian Sejarah Perkembangan Pemikiran Negara, Masyarakat dan Kekuasaan. Jakarta: Gramedia

Supelli, K. (2010). Ruang Publik Dunia Maya. Dalam F. Budi Hardiman (ed). Ruang Publik: Melacak Partisipasi Demokratis dari Polis sampai Cyberspace. Yogyakarta: Kanisius

Syam, M.N. (2000). Pancasila Dasar Negara Republik Indonesia, Wawasan Sosio-Kultural, Filosofis dan Konstitusional. Malang: Laboratorium Pancasila IKIP Malang

Jurnal

Fatkhurohman, \& Ahmad T.W. (2010). Pemilihan Umum Sebagai Wahana Peningkatan Kualitas Demokrasi di Indonesia. Jurnal Konstitusi Puskasi Fakultas Hukum Universitas Widyagama Malang. 
Jafarkarimi, H. et al. (2014). The Impact of ICT on Reinforcing Citizens' Role in Government Decision Making. International Journal of Emerging Technology and Advanced Engineering. Vol.4 January

Lee, C.P. et al. (2011). Testing the Development and Diffusion of E-Government and E-Democracy: A Global Perspective. Public Administration Review. Vol 71, May/June.

Towner, T.L. (2013). All Political Participation Is Socially Networked? New Media and the 2012 Election. Social Science Computer Review. Vol. 31 